\title{
Modifikasi Bentonit Menggunakan Surfaktan Kationik Benzalkonium Klorida
}

\author{
Titik Turmiati', Wirda Udaibah', Mulyatun'1 \\ Jurusan Kimia, Fakultas Sains dan Teknologi, UIN Walisongo Semarang \\ *Email : turmiatititik@gmail.com
}

\begin{abstract}
Abstrak
Bentonit alam yang telah dimodifikasi menjadi organobentonit dengan menggunakan surfaktakan kationik Benzalkonium Klorida sebagai agen penginterkalasi dengan berbagai variasi suhu. Material hasil sintesis diaplikasikan sebagai adsorben untuk penyerapan logam berat berupa ion logam $\mathrm{Zn}^{2+}$. Proses adsorpsi dilakukan dalam berbagai variasi kondisi yaitu $\mathrm{pH}$ dan waktu kontak. Hasil analisis XRD menunjukkan material bentonit yang telah dimodifikasi berhasil di sintesis, hal ini terlihat dari jarak antar lapis pada suhu $50^{\circ} \mathrm{C}$ sebesar $15,06 \AA$, suhu $60^{\circ} \mathrm{C}$ sebesar $16,76 \AA ̊$ dan suhu $70^{\circ} \mathrm{C}$ sebesar $16,50 \AA$ A dibandingkan dengan bentonit alam sebesar $12,09 \AA$. Spektra FTIR menunjukkan serapan pita $2360 \mathrm{~cm}^{-1}$ yaitu adanya vibrasi C-N dan $1465 \mathrm{~cm}^{-1}$ adanya vibrasi $\mathrm{N}-\mathrm{H}$. Hal ini menunjukkan adanya garam ammonium kuartener yang di pada interlayer bentonit. Penentuan $\mathrm{pH}$ optimum dan waktu kontak pada saat adsorpsi. Dari pH 4-8 menunjukkan bahwa pH optimum untuk proses adsorpsi ion logam $\mathrm{Zn}^{2+}$ adalah pH 6 dengan daya adsorpsi sebesar 99,914\%, sedangkan pada bentonit alam sebesar 92,94\%, kemudian untuk waktu kontak adalah di 60-120 menit dengan daya adsorpsi sebesar 97,92\% pada suhu sintesis $60^{\circ} \mathrm{C}$ serta waktu kontak untuk bentonit alam 85,31\%. Data kinetika adsorpsi menggunakan model pseudo second order lebih sesuai untuk menjelaskan proses adsorpsi ion logam $\mathrm{Zn}^{2+}$. Hal ini dapat disimpulkan bahwa bentonit yang telah dimodifikasi memiliki daya adsorpsi ion logam $\mathrm{Zn}^{2+}$ yang lebih besar di bandingkan dengan bentonit yang belum termodifikasi.
\end{abstract}

Kata Kunci : Bentonit; Organobentonit; BKC; Adsorpsi; Ion logam $\mathrm{Zn}^{2+}$.

\begin{abstract}
Natural bentonite which has been modified into organobentite by using cationic surfactation Benzalkonium Chloride as an intercalating agent with various temperature variations. The synthesized material was applied as an adsorbent for the absorption of heavy metals in the form of $\mathrm{Zn}^{2+}$ metal ions. The adsorption process is carried out in a variety of conditions namely $\mathrm{pH}$ and contact time. XRD analysis results showed that the modified bentonite material was successfully synthesized, this can be seen from the distance between layers at a temperature of $50{ }^{\circ} \mathrm{C}$ at $15.06 \AA$, a temperature of $60{ }^{\circ} \mathrm{C}$ at $16.76 \AA$ and a temperature of $70{ }^{\circ} \mathrm{C}$ at $16.50 \AA$ compared to natural bentonite of $12.09 \AA$ A. FTIR spectra showed absorption bands of $2360 \mathrm{~cm}-1$ namely the presence of $\mathrm{C}-\mathrm{N}$ vibrations and $1465 \mathrm{~cm}-1$ of the presence of $\mathrm{N}-\mathrm{H}$ vibrations. This shows the presence of quaternary ammonium salts in the bentonite interlayer. Determination of optimum $\mathrm{pH}$ and contact time at adsorption. From $\mathrm{pH}$ 4-8 shows that the optimum $\mathrm{pH}$ for the $\mathrm{Zn}^{2+}$ metal ion adsorption process is $\mathrm{pH} 6$ with an adsorption power of $99.914 \%$, whereas in natural bentonite is $92.94 \%$, then for contact time it is $60-120$ minutes with adsorption power of $97,92 \%$ at temperatute $60^{\circ} \mathrm{C}$ synthesis temperature and contact time for natural bentonite $85.31 \%$. The adsorption kinetics data using the pseudo second order model is more suitable to explain the $\mathrm{Zn}^{2+}$ metal ion adsorption process. It can be concluded that the modified bentonite has a greater $\mathrm{Zn}^{2+}$ metal ion adsorption power compared to the unmodified bentonite.
\end{abstract}

Keywords: Bentonite; Organobentonite; BKC; Adsorption; $\mathrm{Zn}^{2+}$ metal ions. 


\section{PENDAHULUAN}

$\begin{array}{rrr}\begin{array}{c}\text { Pemerintah } \\ \text { Kementerian }\end{array} & \text { Indonesia } & \text { melalui } \\ \text { Perindustrian } & \text { terus }\end{array}$ mengembangkan industri berbasis kuningan di dalam negeri agar semakin berdaya saing. Salah satu upaya strategisnya adalah mendorong produksi sektor ini melalui pemanfaatan daur ulang bahan baku kuningan atau tembaga dari sisa peralatan rumah tangga atau proyek yang sudah tidak terpakai. Juwana merupakan salah satu Kecamatan di Kabupaten Pati, yang mempunyai aktivitas seni kerajinan kuningan yang cukup menonjol. Produk kerajinan kuningan Juwana ini bahkan sudah menembus pasar internasional. Berdasarkan data yang diperoleh dari dinas Perindustrian dan Perdagangan Kabupaten Pati tahun 2015, di Juwana terdapat 220 buah industri kecil kerajinan kuningan yang berijin dengan jumlah pekerja 5.483 orang (Priyanto,2015).

Selain dampak positif yang ditimbulkan dari adanya industri kuningan, di sisi lain juga timbul permasalahan di lingkungan sekitar seperti: bertambahnya polusi udara dari asap industri, adanya pencemaran air dari limbah pabrik serta banyaknya sumber daya alam yang rusak karena industri (Janti, 2016). Pada industri kuningan yang paling berbahaya adalah dampak pencemaran air, karena di dalamnya mengandung logam berat. Logam berat merupakan pengelompokan unsur-unsur logam yang mempunyai berat jenis lebih dari 5 $\mathrm{g} / \mathrm{cm}^{3}$. (Imanudin, 2012). Logam berat yang termasuk dalam limbah industri kerajinan kuningan adalah $\mathrm{Zn}$.

Logam berat Seng (Zn) merupakan salah satu logam berat yang berbahaya karena sifat karsinogenik yang dimilikinya (Yousef,2012). Kadar normal Zn dalam air menurut WHO adalah 1,5 ppm, sedangkan menurut KLH adalah 0,05 ppm (Imanudin 2012). Zn bersifat racun dalam kadar tinggi, namun dalam kadar rendah dibutuhkan oleh organisme sebagai ko-enzim (Tarigan, 2003).

Oleh karena itu perlu adanya upaya untuk mengurangi atau menghilangkan logam berat $\mathrm{Zn}$ di dalam limbah cair. Ada banyak metode yang telah digunakan yaitu dengan menggunakan proses fisika-kimia diantaranya koagulasi, adsorpsi, flokulasi, pertukaran ion, filtrasi membran dan elektrodialisis. Metode Fisika-kimia dengan jenis adsorpsi dipilih karena efektif, murah, mudah serta praktis untuk adsorpsi limbah cair (Tohdee, 2018).

Adsorben ada dua jenis yaitu biosorben dan adsorben dari bahan mineral. Selama ini untuk menghilangkan beberapa logam berat dan senyawa organik adalah dengan menggunakan bio-adsorben (Chitin, Chitosan, biomassa dan sebagainya). Salah satu mineral yang dapat digunakan sebagai adsorben adalah bentonit. Bentonit mempunyai potensi sebagai adsorben, karena kemampuannya mengadsorp logam berat pada limbah cair (Pandey, 2017). Bentonit sangat menarik untuk diteliti karena lempung ini mempunyai struktur berlapis dengan kemampuan mengembang (swelling) dan memiliki kation-kation yang dapat ditukarkan. Meskipun lempung bentonit sangat berguna untuk adsorpsi, namun kemampuan adsorpsinya terbatas. Perlu dicatat bahwa pengembangan (swelling) dapat mengurangi konduktivitas hidrolik dari tanah alami, sehingga larutan tidak bisa meresap ke lempung dengan mudah. Hal inilah yang menyebabkan lempung alami tidak dapat secara efektif menyerap ion-ion logam dari larutan berair (Daz-Nava, 2012).

Modifikasi bentonit alam diperlukan untuk meningkatkan kapasitas adsorpsi. Surfaktan banyak digunakan untuk modifikasi dengan memanfaatkan sifat tukar kation organiknya (yang memiliki tipe seperti amonium kuartener dan struktur alifatik) dengan anion anorganik (Daz-Nava, 2012). Bentonit dapat dimodifikasi sehingga mempunyai sifat adsorpsi selektif terhadap logam berat. Jenis surfaktan yang sering digunakan para peneliti adalah ammonium kuarterner, misalnya Hexadecyltrimetil Amonium Bromida. Ada banyak metode yang biasa digunakan dalam penelitian seperti, koagulasi, flokulasi dan presipitasi. Metode interkalasi dipilih karena lebih tepat dalam penelitian ini. Hal ini di karenakan struktur

48

Copyright @ 2019 WJC | ISSN 2621-5985 (online) | ISSN 2549-385X (print)

Volume 2, Nomor 2, 2019 
dari bentonit yang memilki kemampuan mengembang (Swelling) serta kemampuan kation-kation yang dapat di tukarkan pada sisi interlayer. Metode interkalasi di dasarkan pada penyisipan suatu logam pada sisi interlayer pada material. Pada proses interkalasi, jenis surfaktan ini akan menghasilkan nanoruang dua dimensi pada antar lapis lempung. Interkalasi ke dalam struktur lempung ini mengakibatkan peningkatan luas permukaan dan $d$-spacing (jarak antar lapis) yang berpengaruh terhadap kapasitas adsorpsinya. Nano ruang dua dimensi ini terjadi melalui interaksi antara ion organoamonium dengan ruang antar lapis silikat sehingga menyebabkan terbukanya ruang pada antar lapis sampai ke ukuran nano. Pertukaran antara kation antar lapis dengan ion organoamonium ini akan menghasilkan perubahan sifat permukaan pada kisi-lapis lempung (Alpes, 2017).

Tingkat adsorpsi $\mathrm{Zn}^{2+}$ meningkat dengan meningkatnya $\mathrm{pH}$, suhu, kecepatan pengadukan, rentang waktu dan dengan penurunan partikel bentonit, konsentrasi awal $\mathrm{Zn}^{2+}$ dan cairan-rasio yang padat . Araujo (2013) menentukan kapasitas adsorpsi $\mathrm{Zn}^{2+}$ oleh lempung bentonit. Bentonit di beri perlakuan panas untuk mengoptimalkan kapasitas adsorpsi. Berdasarkan penelitian yang dilakukan Daz-Nava (2012) berhasil memodifikasi bentonit dengan Bencylhexadecyl Dimethyl Ammonium Chloride (BCDMACl) dan Hexadecyl Trimethyl Ammonium Bromide (HDTMABr), dan menguji bentonit yang termodifikasi surfaktan untuk adsorpsi fenol. Hasilnya, penghilangan fenol tergantung pada beberapa faktor, seperti struktur surfaktan, spesies fenol, $\mathrm{pH}$, dan konsentrasi awal zat terlarut.

Penelitian yang dilakukan oleh Tohdee (2018), hasilnya juga mengungkapkan bahwa bentonit termodifikasi telah meningkatkan kapasitas adsorpsi secara signifikan (maks q 50,76 dan 35,21 mg/g untuk Cu (II) dan Zn (II), masing-masing); peningkatan 2,5 dan 2,0 kali lipat di atas bentonit alam. Studi ini mendemonstrasikan bentonit termodifikasi sebagai adsorben efektif untuk menghilangkan logam berat dari larutan berair.

Berdasarkan latar belakang tersebut, akan dilakukan penelitian mengenai (1) modifikasi bentonit dengan metode interkalasi surfaktan benzalkonium klorida (BKC) ke dalam struktur lempung bentonit yang di pengaruhi oleh suhu (2) uji adsorpsinya terhadap ion logam $\mathrm{Zn}$.

\section{METODOLOGI PENELITIAN}

\begin{abstract}
Alat
Peralatan yang digunakan dalam penelitian ini antara lain botol ampul, gelas beker $250 \mathrm{~mL}$, hotplate magnetic stirrer, tabung reaksi, pipet tetes, gelas ukur, batang pengaduk, oven, neraca analitis, thermometer, dan instrumen $X$-Ray Diffraction, FTIR, dan Atomic Absorption Spectroscopy (AAS).
\end{abstract}

\section{Bahan}

Bahan-bahan yang diperlukan untuk penenlitian adalah bentonit, $\mathrm{CH}_{3} \mathrm{COOH}, \mathrm{NH}_{4} \mathrm{Cl}$, $\mathrm{KCl}, \mathrm{NaOH}, \mathrm{HCl}, \mathrm{AgNO}_{3}, \mathrm{BKC}$ (Benzal Konium Klorida).

\section{Prosedur Kerja}

\section{Kapasitas Tukar Kation}

Dari $1 \mathrm{~g}$ bentonit tersebut di tambah dengan larutan buffer $\mathrm{CH}_{3} \mathrm{COONa} 1 \mathrm{M}$ dengan pH 5 kemudian di aduk dengan magnetic stirrer selama 18 jam. Setelah pengadukan di tambahkan larutan $\mathrm{KCl} 1 \mathrm{M}$ dengan $\mathrm{pH} 7 \mathrm{di}$ aduk dengan menggunakan magnetic stirrer selama 18 jam.

Proses berikutnya adalah tahap penyaringan. Dimana filtratnya diuji dengan menggunakan $\mathrm{AgNO}_{3}$, apabila masih terdapat endapan yang terkandung dalam filtrat maka residu dicuci dengan menggunakan aquadest sampai tidak terbentuk endapan. Dengan langkah yang sama, maka percobaan ini diulang satu kali lagi. Kemudian residu di tambahkan dengan larutan $\mathrm{NH}_{4} \mathrm{Cl}$ 0,2 $\mathrm{M}$ dan di aduk selama 6 jam. Setalah itu di saring, residu di tambahkan dengan larutan $\mathrm{NH}_{4} \mathrm{Cl}$ 0,2 $\mathrm{M}$ di aduk selama 10 menit. Proses yang terakhir 
adalah penyaringan, filtrat kemudian dianalisa dengan menggunakan Atomic Absorbtion Spectroscopy (AAS) untuk mengetahui kadar kalium yang masih tersisa.

\section{Modifikasi Bentonit}

Campuran diaduk menggunakan magnetic stirerr selama 48 jam dengan suhu 50,60 , dan $70^{\circ} \mathrm{C}$. Setelah itu dipisahkan antara residu dan filtrat. Residu kemudian dicuci dengan menggunakan aquadest untuk menghilangkan kelebihan surfaktan yang masih ada pada bentonit. Sampel yang berbentuk padat dipanaskan dengan menggunakan oven selama 24 jam. Tahap akhir adalah di analisa dengan menggunakan FTIR dan XRD, baik sampel yang sudah di modifikasi maupun bentonit yang belum di modifikasi.

\section{Penentuan pH Optimum Bentonit dan Organobentonit}

Prosedur penentuan $\mathrm{pH}$ optimum di lakukan dengan cara: ke dalam 5 buah erlenmayer $250 \mathrm{~mL}$, dimasukkan masingmasing 0,5 gram organobentonit dan ditambahkan $25 \mathrm{~mL}$ larutan sampel dengan $\mathrm{pH}$ larutan optimum yaitu antara 4-8 dengan penambahan $\mathrm{HCl} 1 \mathrm{M}$ atau $\mathrm{NaOH} 1 \mathrm{M}$. Kemudian diaduk dengan menggunakan magnetic stirrer selama 24 jam. Selanjutnya campuran di saring dan filtratnya dimasukkan ke dalam labu takar $50 \mathrm{~mL}$, kemudian ditambahkan dengan aquadest. Setelah itu ditentukan konsentrasi ion $\mathrm{Zn}$ (II) setelah adsorpsi. pH optimum bentonit tanpa modifikasi ditentukan sebagai kontrol dengan prosedur yang sama.

\section{Penentuan Waktu Kontak Optimum Bentonit dan Organobentonit}

8 buah erlenmeyer $25 \mathrm{~mL}$ dimasukkan masing-masing 0,5 gram contoh butiran organobentonit dan ditambahkan $25 \mathrm{~mL}$ larutan $\mathrm{ZnSO}_{4} 100$ ppm dengan $\mathrm{pH}$ optimum yang diperoleh. Campuran diaduk menggunakan pengaduk magnet selama 15,30 , 45, 60, 75, 90, 105, 120 menit. Selanjutnya campuran disaring dan filtratnya dimasukkan ke dalam labu takar $50 \mathrm{~mL}$, kemudian diimpitkan dengan akuades, kemudian ditentukan konsentrasi Zn setelah adsorpsi. Waktu optimum bentonit tanpa modifikasi ditentukan sebagai kontrol dengan prosedur yang sama.

\section{Analisa Data}

Tujuan dilakukan pengukuran ini adalah untuk menentukan kapasitas tukar kation pada material bentonit. Kapasitas tukar kation pada bentonit (meq/100g), dapat dihitung dengan menggunakan rumus sebagai berikut:

$$
\text { KTK : } \frac{100 \times(C \text { awal-C akhir }) \mathrm{x} \text { Vanion }}{\text { Berat Material }}
$$

Keterangan:

$\begin{array}{ll}\mathrm{C}_{\text {awal }} & : \text { Konsentrasi Awal (mg/L) } \\ \mathrm{C}_{\text {akhir }} & : \text { Konsentrasi Akhir (mg/L) } \\ \mathrm{V}_{\text {anion }} & : \text { Volume Anion (L) }\end{array}$

Uji kapasitas adsorpsi, dilakukan berdasarkan penentuan $\mathrm{pH}$ optimum. Tujuan dari uji kapasitas adsorpsi untuk mengetahui seberapa banyak adsorben dapat menyerap ion Zn (II) secara maksimum. Adapun perhitungan yang digunakan adalah sebagai berikut :

$$
\mathrm{Q}: \frac{(\mathrm{C} \text { awal-C akhir)x Vanion }}{m}
$$

Keterangan:

Q : Kapasitas adsorpsi (mg/g)

$C_{\text {awal }}$ : Konsentrasi Awal (mg/L)

$\mathrm{C}_{\text {akhir }}$ : Konsentrasi Akhir (mg/L)

$\mathrm{V}_{\text {anion }}$ : Volume Anion (L)

$\mathrm{m} \quad$ : Massa adsorben (g)

Adapun untuk perhitungan \% Adsorpsi yang digunakan adalah sebagai berikut :

$\%$ Adsorpsi $=\frac{\left(C_{\text {awal }}-C_{\text {akhir }}\right)}{100} \times 100 \%$

Keterangan :

$\mathrm{C}_{\text {awal }} \quad$ : Konsentrasi Awal (mg/L)

$\mathrm{C}_{\text {akhir }} \quad$ : Konsentrasi Akhir (mg/L)

Kinetika adsorpsi digunakan dalam menghitung adsorpsi berdasarkan parameter kinetik. Kinetika adsorpsi dipelajari melalui 
variasi waktu kontak adsorpsi dan laju adsorpsi material bentonit yang termodifikasi surfaktan Benzalkonium Klorida. Kinetika adsorpsi dihitung dengan menggunakan persamaan pseudo first order dan pseudo second order sebagai berikut:

$\log (\mathrm{Q} e-\mathrm{Qt})=\log \mathrm{Qe}-\frac{\mathrm{K} 1}{2,303} \mathrm{t}$

$\frac{\mathrm{t}}{\mathrm{Qt}}=\frac{1}{\mathrm{~K}_{2} \mathrm{Qe}^{2}}+\frac{1}{\mathrm{Qe}} \mathrm{t}$

\section{Keterangan :}

Qe =Kapasitas adsorpsi pada kesetimbangan (mg/g)

Qt = Kapasitas adsorpsi pada $\mathrm{t}(\mathrm{mg} / \mathrm{g})$

$\mathrm{t}=$ waktu adsorpsi

$\mathrm{k}_{1}=$ Konstanta laju adsorpsi kinetik pada $p s e u d o$ first order(menit ${ }^{-1}$ )

$\mathrm{k}_{2}=$ Konstanta laju adsorpsi kinetik pada pseudo second $\operatorname{order}\left(\right.$ menit $\left.^{-1}\right)$

\section{Hasil dan Pembahasan}

\section{Penentuan Kapasitas Tukar Kation}

Penentuan kapasitas tukar kation ini bertujuan untuk mengetahui seberapa banyak kation yang telah ditukarkan pada suatu material bentonit. Pada penelitian yang dilakukan memperoleh kapasitas tukar kation pada material bentonit sebesar 66,02 meq. Studi sebelumnya yang dilakukan oleh Bourgas (2018) menunjukkan bahwa kapasitas tukar kation sebnyak 4-12 meq, dengan pertukaran kation antara kalium dan Butyl Diammonium Diklorida. Studi yang dilakukan oleh Tohdee (2018) menunjukkan bahwa antara kalium dan Cesium Klorida ( $\mathrm{CsCl}$ ) sebesar 75,95 meq.

Hasil ini menunjukkan bahwa semkain besar kation yang ditukarkan pada interlayer bentonit, maka kapasitas pertukaran kationnya semakin kecil. Hasil kapasitas tukar kation ini yang nantinya akan digunakan untuk menentukan seberapa banyak surfaktan yang akan digunakan untuk menentukan modifikasi pada tahap selanjutnya.

\section{Karakterisasi menggunakan FTIR}

Tujuan dilakukannya

analisa

menggunakan FTIR (Fourier Transform Infrared) adalah untuk mengetahui gugus fungsi yang ada dalam material baik sebelum di modifikasi maupun sesudah di modifikasi. Berdasarkan penelitian yang dilakukan oleh Monteiro (2018) menyatakan bahwa bentonit yang belum dimodifikasi dan setelah dimodifikasi ada perubahan gugus fungsi, diantaranya adalah gugus fungsi $\mathrm{C}-\mathrm{H}, \mathrm{N}-\mathrm{H}$. Gugus fungsi ini berasal dari surfaktan kationik.

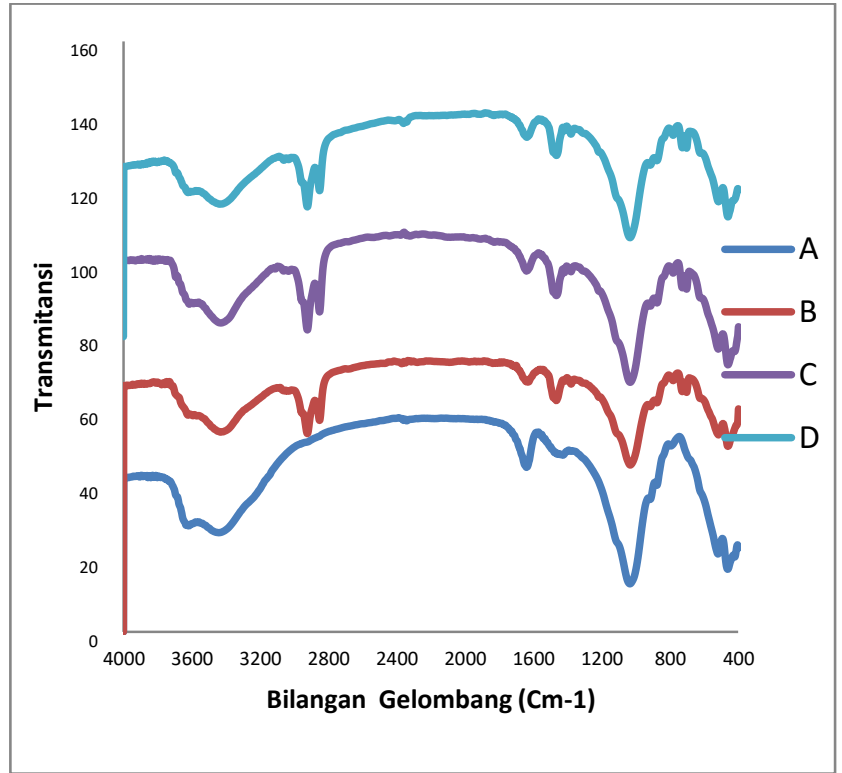

Gambar 1. A) Bentonit alam, B) Organobentonit pada suhu $50^{\circ} \mathrm{C}, \mathrm{C}$ ) Organobentonit pada suhu $\left.60^{\circ} \mathrm{C}, \mathrm{D}\right)$ Organobentonit pada suhu $70^{\circ} \mathrm{C}$

Hasil karakterisasi menunjukkan bahwa spektrum bentonit yang belum di modifikasi dan bentonit telah dimodifikasi dengan menggunakan surfaktan pada suhu $50^{\circ} \mathrm{C}, 60^{\circ} \mathrm{C}$ dan $70^{\circ} \mathrm{C}$. Ada perbedaan dan persamaan Perbedaan gugus fungsinya.

Persamaan gugus fungsinya secara umum muncul serapan pita pada $3432 \mathrm{~cm}^{-1}$ karena ada getaran peregangan kelompok $\mathrm{O}-\mathrm{H}$ yang berasal dari gugus hidroksil struktural Na-bentonit. Serapan pita pada $2852 \mathrm{~cm}^{-1}$ dan $2924 \mathrm{~cm}^{-1}$ menunjukkan adanya gugus metilen $\left(\mathrm{CH}_{2}\right)$ simetris dan asimetris yang menunjukan adanya peningkatan surfaktan kationik dari 
Benzalkonium Klorida (Luo, 2015). Serapan pita di $1033 \mathrm{~cm}^{-1}$ menunjukkan adanya peregangan Si-O-Si (Zhuang, 2016). Serapan pita di $876 \mathrm{~cm}^{-1}$ menunjukkan adanya peregangan $\mathrm{Al}-\mathrm{Fe}-\mathrm{OH}$ dan $781 \quad \mathrm{~cm}^{-1}$ mengindikasikan bahwa bentonit mengandung quarsa (Dutta,2014), serta serapan pita pada $519 \mathrm{~cm}^{-1}$ mengindikasikan adanya peregangan Si-O yang berasal dari $\mathrm{SiO}_{4}$ yang berbentuk tetrahedral (Liao, 2016).

Perbedaan spektranya terletak pada suhu $50^{\circ} \mathrm{C}$ muncul pita serapan pita pada 3777 $\mathrm{cm}^{-1}$ menunjukkan adanya perengan Al-O-Al (Monterio, 2018) dan pada suhu $70^{\circ} \mathrm{C}$ muncul pada pita serapan $2360 \mathrm{~cm}^{-1}$ adanya vibrasi CN. Serapan pita juga muncul juga pada 1465 $\mathrm{cm}^{-1}$ yang menunjukkan adanya vibrasi $\mathrm{N}-\mathrm{H}$. Hal ini menunjukkan sampel mengandung garam Ammonium Kuartener (Monterio, 2018).

\section{Karakterisasi Menggunakan XRD}

Tujuan dilakukan analisa menggunakan XRD (X-ray Difracction) untuk menentukan sistem kristal. Berdasarkan penelitian ini maka di peroleh bentuk difraktogram dari bentonit alam dan bentonit temodifikasi (organobentonit) adalah sebagai berikut:

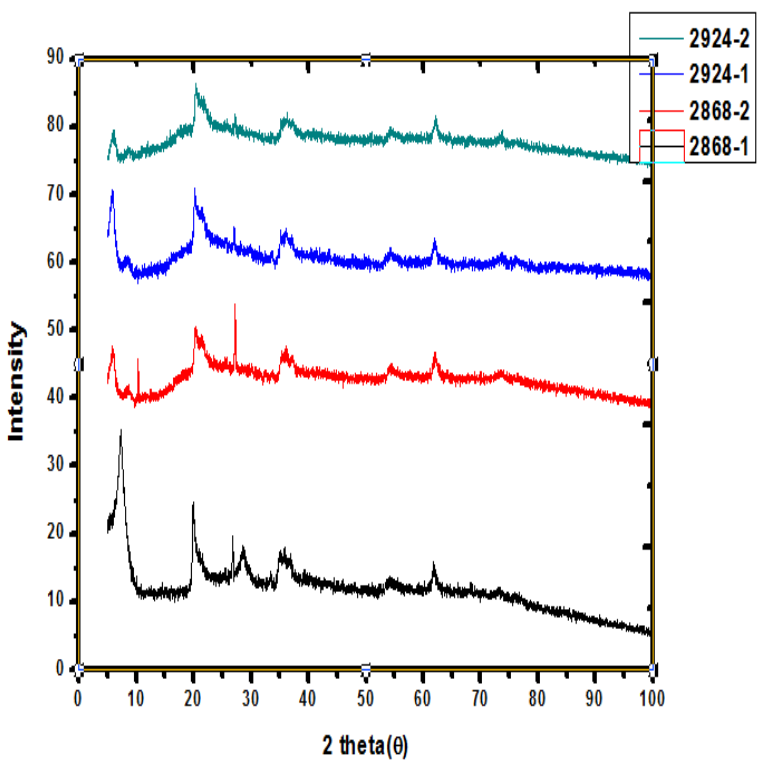

Gambar 2. XRD bentonit alam Organobentonit dengan suhu $50^{\circ} \mathrm{C}, 60^{\circ} \mathrm{C}$ dan $70^{\circ} \mathrm{C}$.
Tabel 1. Besar nilai $d$-spacing pada bentonit dan organobentonit

\begin{tabular}{ccc}
\hline Sample & $2 \theta$ & d-spacing \\
\hline Bentonit alam & $7,03^{\circ}$ & 12,09 \\
$\begin{array}{c}\text { Organobentonit } \\
50^{\circ} \mathrm{C}\end{array}$ & $5,08^{\circ}$ & 15,06 \\
& & \\
$\begin{array}{c}\text { Organobentonit } \\
60^{\circ} \mathrm{C}\end{array}$ & $5,26^{\circ}$ & 16,76 \\
& & \\
$\begin{array}{c}\text { Organobentonit } \\
70^{\circ} \mathrm{C}\end{array}$ & $5,35^{\circ}$ & 16,50 \\
\hline
\end{tabular}

Berdasarkan tabel 1 menunjukkan adanya peningkatan nilai $d$-spacing pada interlayer bentonit. Suhu yang digunakan semakin tinggi akan mempengaruhi proses interkalasi, dimana penambahan surfaktan pada suhu $70^{\circ}$ nilai d-spacingnya menurun. Seharusnya kenaikan temperatur dilakukan maka yang terjadi pergerakan dari molekul akan bergerak jauh lebih cepat sehingga yang terjadi adalah senyawa interkalar dapat masuk kedalam ruang antar lapisan material bentonit. Tetapi terdapat temperatur kritis dimana suatu proses integrasi dapat berlangsung. Ketika lewat dari temperatur kritis tersebut maka interaksi antara interkalan dengan bentonit akan melemah sehingga menjadikan interlayer menurun (Phatak, 2018).

\section{Kapasitas Adsorpsi}

\section{a. Pengaruh pH pada kapasitas adsorpsi}

Variasi pengaruh $\mathrm{pH}$ pada ion logam $\mathrm{Zn}^{2+}$ untuk material bentonit alam dan bentonit termodifikasi surfaktan kationik Benzalkonium Klorida. Adsorpsi dilakukan dengan menggunakan larutan $\mathrm{ZnSO}_{4}$ konsentrasi $100 \mathrm{mg} / \mathrm{L}$. pH yang digunakan mulai dari $\mathrm{pH}$ 4-8. Berat adsorben yang digunakan pada masing-masing variasi adalah 0,5 gram

Kapasitas adsorpsi ion $\mathrm{Zn}^{2+}$ juga semakin meningkat dengan meningkatnya $\mathrm{pH}$ yang digunakan. Hal ini dapat dilihat dari $\mathrm{pH} 4-$

52

Copyright @ 2019 WJC | ISSN 2621-5985 (online) | ISSN 2549-385X (print)

Volume 2, Nomor 2, 2019 
6 dapat mengalami peningkatan daya adsorpsi. pH 6-8 mengalami kesetimbangan adsorpsi pada bentonit alam maupun organobentonit.

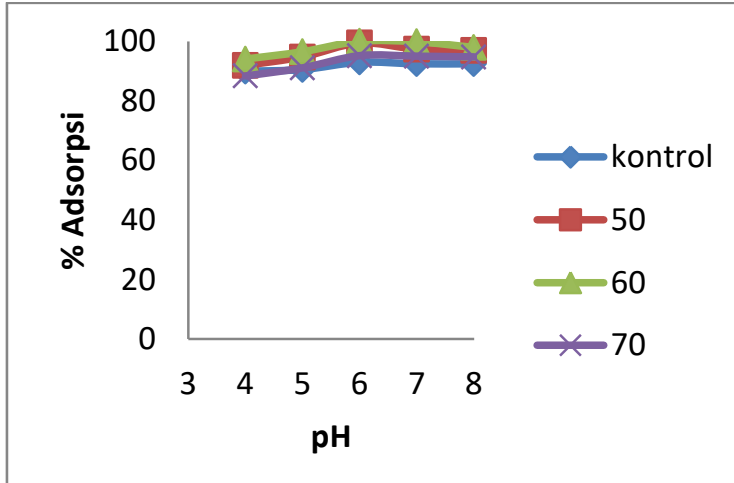

Gambar 2. Pengaruh pH pada berbagai variasi suhu sintesis terhadap \% adsorbsi bentonit dan organobetonit

Bentonit dan organobentonit akan mengalami adsorpsi maksimum pada $\mathrm{pH}$ asam untuk adsorpsi ion $\mathrm{Zn}^{2+}$. Kondisi asam akan mempengaruhi gugus-gugus fungsional pada adsorben akan mudah terprotonasi. Sehingga akan terjadi persaingan antara ion logam $\mathrm{Zn}^{2+}$ dan proton dalam berinteraksi dengan adsorben. Pada $\mathrm{pH}$ diatas 7 , adsorpsi $\mathrm{Zn}^{2+}$ mengalami penurunan, hal ini dimungkinkan terjadi peningkatan konsentrasi $\mathrm{OH}^{-}$pada larutan $\mathrm{Zn}^{2+}$, dimana logam $\mathrm{Zn}^{2+}$, mulai mengendap sebagai $\mathrm{Zn}(\mathrm{OH})_{2}$ yang sukar larut dalam air. Hal ini sesuai dengan harga Ksp $\mathrm{Zn}(\mathrm{OH})_{2}$ yaitu $3.0 \times 10^{-16}$ (Yunitawati, 2011).

Pengaruh $\mathrm{pH}$ terhadap kapasitas adsorpsi dapat ditunjukkan dari interaksi elektrostatik antara permukaan organobentonit dengan $\mathrm{Zn}^{2+}$ dalam larutan, yaitu permukaan organobentonit bermuatan negatif pada $\mathrm{pH}$ lebih dari 10 dan bermuatan positif pada pH kurang dari 10 (Arias, 2009). Hal ini menunjukkan pada $\mathrm{pH}$ lebih dari 10 akan terjadi tolakan elektrostatik di permukaan antara organobentonit dan $\mathrm{Zn}^{2+}$ yang sama-sama bermuatan negatif, sebaliknya pada pH kurang dari 10 terjadi interaksi elektrostatik antara organobentonit yang bermuatan positif dengan anion $\mathrm{Zn}^{2+}$ yang bermuatan negatif. Muatan positif permukaan meningkat dengan menurunnya $\mathrm{pH}$, hal ini menyebabkan kapasitas adsorpsi $\mathrm{Zn}^{2+}$ oleh organobentonit optimum pada $\mathrm{pH}$ rendah.

\section{b. Pengaruh Waktu Kontak terhadap Daya Adsorpsi dan Kinetika Adsorpsi}

Penentuan waktu optimum adsorpsi dilakukan untuk mengetahui waktu minimum yang dibutuhkan oleh adsorben dalam mengadsorpsi ion logam $\mathrm{Zn}^{2+}$ secara maksimum sampai tercapai keadaan jenuh. Adsorpsi dilakukan dengan menggunakan larutan $\mathrm{ZnSO}_{4}$ konsentrasi $100 \mathrm{mg} / \mathrm{L}$ yang diatur pada nilai pH 6 dengan variasi waktu kontak adsorben dan adsorbat selama 15, 30, 45, 60, 75, 90, 105 dan 120 menit. Data yang diperoleh digunakan untuk menentukan parameter kinetika, yakni konstanta laju adsorpsi dengan model kinetika pseudo first order dan pseudo second order. Data adsorpsi ion logam $\mathrm{Zn}^{2+}$ terhadap variasi waktu kontak tersaji pada lampiran dan grafik ditunjukan pada grafik berikut.

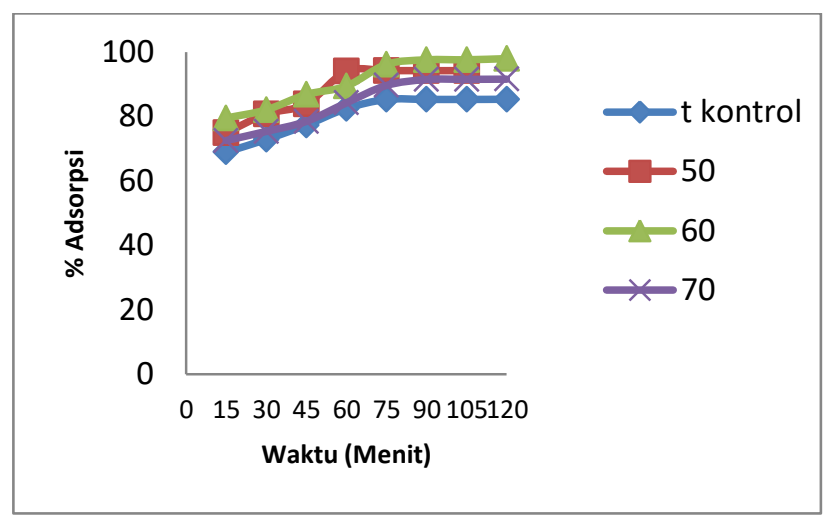

Gambar 3. Pengaruh waktu kontak pada berbagai variasi suhu sintesis terhadap \% adsorbsi bentonit dan organobetonit. 
Penambahan waktu kontak adsorben dan adsorbat pada menit 15 sampai 45 menit mengalami kenaikan, sedangkan pada menit ke 60 sampai 120 menit menghasilkan kapasitas adsorpsi ion logam $\mathrm{Zn}^{2+}$ mencapai kesetimbangan. Hal ini ditunjukan dari jumlah ion logam $\mathrm{Zn}^{2+}$ teradsorpsi yang relatif konstan yakni sebesar 97,92 mg/L. Adsorpsi ion logam $\mathrm{Zn}^{2+}$ menggunakan material bentonit yang termodifikasi surfaktan kationik Benzalkonium Klorida menunjukan bahwa terjadi kenaikan jumlah ion logam $\mathrm{Zn}^{2+}$ teradsorpsi dari material.

Ketika mencapai kesetimbangan adsorpsi menggunakan material bentonite termodifikasi pada suhu $50{ }^{\circ} \mathrm{C}$ menunjukkan jumlah ion logam $\mathrm{Zn}^{2+}$ teradsorpsi sebesar $94,27 \mathrm{mg} / \mathrm{L}$ dan untuk material bentonit termodifikasi pada suhu $60{ }^{\circ} \mathrm{C}$ menunjukkan jumlah ion logam $\mathrm{Zn}^{2+}$ teradsorpsi sebesar $97,92 \mathrm{mg} / \mathrm{L}$, serta pada suhu $70{ }^{\circ} \mathrm{C}$ menunjukkan jumlah ion $\mathrm{Zn}^{2+}$ teradsorpsi sebesar 91, $54 \mathrm{mg} / \mathrm{L}$. Gambar menunjukkan bahwa modifikasi bentonit termodifikasi pada suhu $60{ }^{\circ} \mathrm{C}$ menghasilkan jumlah ion logam $\mathrm{Zn}^{2+}$ yang teradsorpsi semakin banyak.

Data yang di peroleh digunakan untuk menentukan kinetika adsorpsi untuk ion logam Zn2+ baik bentonit alam maupun organobentonit.

Tabel 2. Konstanta model kinetik dalam adsorpsi ion logam $\mathrm{Zn}^{2+}$ terhadap pengaruh waktu adsorpsi.

\begin{tabular}{|c|c|c|c|c|c|}
\hline \multirow[b]{2}{*}{ Model Kinetika } & \multirow[b]{2}{*}{ Parameter } & \multirow[b]{2}{*}{ Bentonit Alam } & \multicolumn{3}{|c|}{ Organobentonit } \\
\hline & & & Suhu $50^{\circ} \mathrm{C}$ & $\begin{array}{l}\text { Suhu } \\
60^{\circ} \mathrm{C}\end{array}$ & Suhu $70^{\circ} \mathrm{C}$ \\
\hline Pseudo First & $\begin{array}{l}\text { Qe eksperiment } \\
\left(\mathrm{mg} / \mathrm{g}^{-1}\right)\end{array}$ & 85,313 & 94,275 & 97,924 & 91,545 \\
\hline Order & $\begin{array}{c}(\mathrm{mg} / \mathrm{g}) \\
\mathrm{K}_{1}(\mathrm{~g} / \mathrm{mg} \min ) \\
\mathrm{R}^{2}\end{array}$ & $\begin{array}{c}102,32 \\
0,077 \\
0,869\end{array}$ & $\begin{array}{l}74,43 \\
0,075 \\
0,865\end{array}$ & $\begin{array}{c}47,86 \\
0,04 \\
0,811\end{array}$ & $\begin{array}{c}159,58 \\
0,07 \\
0,861\end{array}$ \\
\hline $\begin{array}{l}\text { Pseudo Second } \\
\text { Order }\end{array}$ & $\begin{array}{c}\text { Qe eksperiment } \\
\text { (mg/g) } \\
\text { Qe Perhitungan } \\
\text { (mg/g) } \\
\mathrm{K}_{2}(\mathrm{~g} / \mathrm{mg} \mathrm{min}) \\
\mathrm{R}^{2}\end{array}$ & $\begin{array}{l}85,313 \\
\\
9,009 \\
0,191 \\
0,998\end{array}$ & $\begin{array}{c}94,275 \\
104,04 \\
0,001 \\
0,998\end{array}$ & $\begin{array}{c}97,924 \\
104,17 \\
0,001 \\
0,997\end{array}$ & $\begin{array}{c}91,545 \\
98,039 \\
0,001 \\
0,997\end{array}$ \\
\hline
\end{tabular}

54 


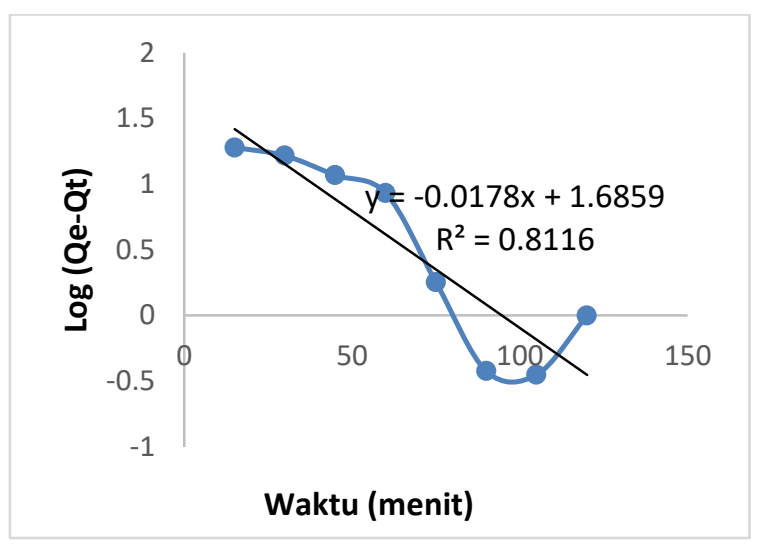

Gambar 4. Kinetika reaksi Pseudo First order pada organobentonit suhu $60^{\circ} \mathrm{C}$

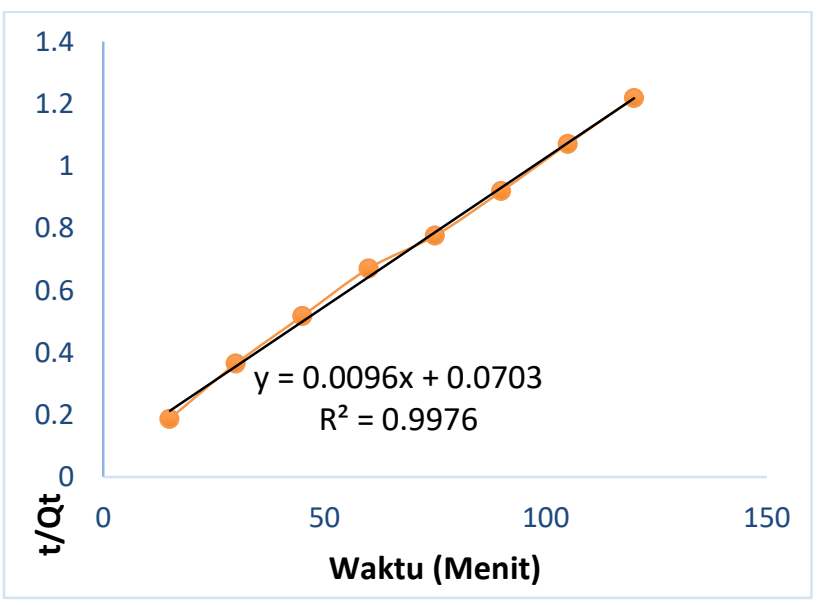

Gambar 5. Kinetika reaksi Pseudo Second order pada organobentonit suhu $60^{\circ} \mathrm{C}$

Dari data yang diperoleh pada Tabel 2 menunjukan nilai koefisien korelasi $\left(\mathrm{R}^{2}\right)$ dari kedua persamaan kinetika yakni persamaan pseudo first order dan persamaan pseudo second order. Persamaan kinetika adsorpsi pseudo second order lebih sesuai digunakan dalam menjelaskan fenomena laju adsorpsi ion logam $\mathrm{Zn}^{2+}$ menggunakan material bentonit alam maupun bentonit termodifkasi. Hal ini dikarenakan nilai koefisien korelasi persamaan garis lurus persamaan pseudo second order lebih mendekati nilai 1. Laju reaksi dari adsorpsi ion logam $\mathrm{Zn}^{2+}$ menggunakan material bentonit alam dan bentonit termodifikasi dapat diamati melalui nilai konstanta laju reaksi adsorpsi $\left(\mathrm{k}_{2}\right)$.

\section{Simpulan}

Modifikasi bentonit menjadi organobentonit sangat dipengaruhi oleh suhu, semakin tinggi suhu maka akan mempercepat pergerakan molekul untuk masuk kedalam interlayer bentonit. Suhu maksimum yang diperoleh pada saat interkalasi adalah $60^{\circ} \mathrm{C}$. Hal ini dibuktikan dari nilai $d$-spacing 16,76 dan daya adsorpsi yang tinggi yaitu 99,65 \%. Interkalasi surfaktan Benzalkonium Klorida ke dalam bentonit dapat meningkatkan kapasitas adsorpsi dari yang semula $4,95 \mathrm{mg} / \mathrm{g}$ menjadi $4,98 \mathrm{mg} / \mathrm{g}$.

\section{Daftar Pustaka}

Alpes, A., Rossa, P., Morales, A. 2017. Evaluation of Organic Modification of Monmorillonite with ionic and non ionic surfactants. Applied clay science 150. 2333.

Araujo, A., Bertagnolli, C., Silva, M. 2013. Zinc adsrption in bentonite clay influence of $\mathrm{pH}$ and initial consentration. Acta Scientiarum Technology 35(2) : 325-332.

Arias, F., Sen, K.T. 2009. Removal Of Zinc Metal Ion (Zn2+) From Its Aqueous Solution By Kaolin Clay Mineral: A Kinetic And Equilibrium Study. Colloids and Surfaces A: Physicochem. Eng. Aspects $348,100-$ 108

Bourgas, Ann \& Stefan, S. 2018. CEC Input To Evaluate The Butyl Diammonium Dichloride As A Swelling Reducer In Clay Rich Material. Applied Clay Science 152 352-356.

Diaz- Nava, M.c. 2012. Adsorption of Phenol Onto Surfactants Modified Bentonite. J Incl Phenom Macrocycl Chem 74: 67-75.

Dutta, A., Singh, N. 2015. Surfactant-Modified Bentonite Clays: Preparation, Characterization , And Atrazine Removal. Environ Sci Pollut Res. 22 3876-3885.

Fadhi, M.R. 2018. Sinesis Material Hidroksi Lapis Ganda Zn-Fe Terinterkalasi 
Senyawa Polioksometalat Tipe Keggin Serta Aplikasinya Sebagai Adsorben Malachite Green. Skripsi. Palembang: Universitas Sriwijaya.

Imanudin. 2012. Zinc in Drinking Water, Background Document for Development of WHO Guidelines for Drinking Water Quality. Inc. New York.

Janti, W. 2016. Adsorpsi dan Desorpsi Ion Kromium (IV) pada Bentonit yang Dimodifikasi

Heksadesiltrimetilamonium Bromida. Skripsi. Bogor: IPB.

Liao, YF., Chang, YT., Lee, JF., 2016. Immobilization Of Fungal Laccase Onto A Nonionic Surfactant-Modified Clay Material: Application To PAH Degradation. Environ Sci Pollut Res Int. Mar;23(5):4024-35.

Luo, W., Ssaki Colloids And Surface A : Physochem, K., Hirajina, T. 2015. Surfactant- Modified Monmorillonite By Benzyl Octadecyldimethyl Ammonium Chloride For Removal of Percholarate. Eng. Aspects 481 616-625.

Monteiro, S.K., Oliveira, V., Santos, F.K. 2018. Influence of The Ionic And Nonionic Surfactants Mixture In The Structure And Properties of The Modified Bentonite Clay. Journal of Molecular Liquids. S0167-7322(18)30636-6.
Phatak, A., Rahane, T. 2018. Intercalation of Itraconazole Into Montmorillonite: Effect On Release Of Drug. World Journal of Pharmaceutical And Medical Research, 4(12), 179-183.

Pandey, Sadanan. 2017. A Comprehensive Review On Recent Devolepments In Bentonit Based Materials Used As Adsoebens For Wastewater Treatment. Journal Of Molecular Liquid.

Priyanto, Agus. 2015. Sentra Promosi dan Informasi Kerajinan Kuningan Juwana. Skripsi. Semarang: Universitas Dipongoro.

Tarigan. 2003. Heavy Metal Biosorption From aqueous solution by Algae Inhibiting Rive Paddies in Vietnam, J. Environ. Chem, Eng 4(2) 2529-2535.

Tohdee, k., Kaesichan, L., Asadullah. 2018. Enhancement of Adsorption Efficiency of Heavy Metal $\mathrm{Cu}$ (II) and Zn (II) Onto Cationic Surfactan Modified Bentonite. Journal Environmental Chemical Engeneering.

Yunitawati., Nurmasari,R., Mujiyanti,R.D., 2011. Kajian Ph Dan Waktu Kontak Optimum Adsorpsi Cd(Ii) Dan Zn(Ii) Pada Humin. Jurnal Ilmiah Berkala Sains dan Terapan Kimia. Vol 5, No 2.

Yousef. 2012. Methodes of removing heavy metal from Industrial wastewater, JMESS. 1(1)1309-2912. 